Izabela Skoczeń

\title{
Marmor kontra Kelsen, czyli kto kogo i dlaczego próbuje zredukować?
}

\section{Wprowadzenie}

Co sprawia, że żądanie kierowcy wobec współpasażera podróży, aby zapiął pasy bezpieczeństwa, nie jest prawem, a co najwyżej pobożnym życzeniem? Dlaczego to samo żądanie zawarte w tekście ustawy jest już prawem? Hans Kelsen w swoim dziele Reine Rechtslehre udzielił na to pytanie bardzo przekonującej, szczególnie dla pozytywisty, odpowiedzi. Każda norma ustawowa wywodzi swoją moc prawną od normy wyższej w hierarchii norm danego systemu. Ustawowy nakaz wywodzi więc swoją moc prawną od norm zawartych w konstytucji. Pojawia się problem, skąd wywodzą swoją moc normy samej konstytucji, skoro, przynajmniej w krajowym porządku prawnym, stoją one najwyżej w hierarchii norm? ${ }^{1}$ Według Kelsena moc prawna norm konstytucyjnych wywodzi się z mocy prawnej normy podstawowej (Grundnorm), która musi być założona. To dzięki niej dany system prawny dostarcza nam wzorców powinnego działania. Przyjrzymy się zatem bliżej normie podstawowej. Ma ona odpowiadać na pytanie o źródło

1 Hans Kelsen (wraz ze swoim uczniem Herschem Lauterpachtem) rozważał także, czy normy konstytucyjne nie czerpią swojej mocy prawnej z norm prawa międzynarodowego publicznego i czy nie istnieje jedna wspólna dla wszystkich systemów prawnych norma podstawowa, wywodząca się z prawa międzynarodowego publicznego. Ponieważ Andrei Marmor w swoich rozważaniach pomija tę kwestię, tutaj również zostanie ona pominięta.

Należy również zaznaczyć, że kwestia najwyższego umiejscowienia konstytucji w hierarchii norm może dzisiaj budzić wątpliwości w świetle prawa Unii Europejskiej. Polski Trybunał Konstytucyjny broni twardo stanowiska, wedle którego konstytucja jest najwyższym źródłem prawa, natomiast Trybunał Sprawiedliwości Unii Europejskiej w Luksemburgu podkreśla nadrzędność europejskiego systemu prawnego, a także konieczność zgodności krajowych porządków prawnych z prawem wspólnot europejskich w dziedzinach, które ono normuje. Zjawisko multicentrycznych systemów prawnych stanowi poważne wyzwanie dla teorii Kelsena. Szczególnie wątpliwa jest kwestia normy podstawowej, bowiem nie jest jasne, czy powinna istnieć jedna wspólna dla wszystkich państw członkowskich norma podstawowa systemu prawa europejskiego, czy wręcz przeciwnie - istnieje tyle norm podstawowych, ile jest państw członkowskich. 
normatywności, obecnie definiowanej bardzo różnie w naukach prawnych, np. jako zdolność do dostarczania racji postępowania zgodnie z danym systemem prawnym. Takich racji postępowania można poszukiwać na wiele sposobów. Jednym z nich jest redukcja, definiowana wielorako: 1) jako redukcja semantyczna, gdy siatkę pojęciową teorii T1 można w pełni wyrazić za pomocą aksjomatów i siatki pojęciowej danej teorii T2, bądź 2) jako konstytutywna albo metafizyczna redukcja, czyli taka, która pozwala wyjaśnić jedno zjawisko za pomocą innego zjawiska albo zespołu faktów².

Hans Kelsen, budując swoją wizję prawa, chciał uniknąć jakiejkolwiek redukcji prawa do wszelkich faktów (czyli redukcji konstytutywnej). Tymczasem Andrei Marmor w swojej książce Philosophy of Law stara się wykazać, że Kelsenowi nie udało się uciec od redukcjonizmu, przynajmniej w zakresie definiowania prawa, natomiast zamierzenie to powiodło się w zakresie definiowania nauk prawnych. Twierdzi on, że Kelsen nie uniknął redukcji konstytutywnej (redukcji prawa do faktów socjologicznych), natomiast operacja ta powiodła się w zakresie redukcji semantycznej (w teorii Kelsena nie ma redukcji nauk prawnych do innych nauk społecznych). Przyjrzyjmy się zatem bliżej argumentom Marmora i zastanówmy się, czy tworzą one spójną całość.

\section{Argumenty Marmora}

Dla Marmora sedno normy podstawowej to kwestia obowiązywania danego sytemu prawnego (validity), która jest zależna od efektywności tego syste$\mathrm{mu}\left(\right.$ efficacy) ${ }^{3}$. Efektywność z kolei jest pojęciem socjologicznym, jest to fakt

2 A. Marmor, Philosophy of Law, Princeton 2011, s. 13-14: „Different conceptions of what would count as a reductive explanation may be relevant to different domains. One type of reduction, which is sometimes called semantic, would have to satisfy the condition that the basic vocabulary of a theory, say T1, could be fully expressed by the axioms and vocabulary of a different theory, T2. If this condition is met, then we have a full semantic reduction of T1 to T2. Very few legal theorists have thought about reduction in this semantic sense (with the exception, perhaps, of John Austin, discussed in the next chapter). The type of reduction more relevant to legal theory is constitutive or metaphysical: The idea of a metaphysical reduction is to show that a distinct type of phenomenon is actually constituted and fully explicable by a different, more foundational, type of phenomenon or set of facts. Philosophers also discuss a third type of reduction or quasi-reduction, called supervenience: A realm $X$ would supervene on realm $Y$ if and only if there are no changes or modifications observable in $Y$ without corresponding observable changes or modifications in $X$. The question of whether supervenience is a genuine reductive relation or not is debated in the literature".

3 Ibidem, s. 22: „What is the content of the basic norm that one needs to presuppose in order to render positive law intelligible as a normative legal order? The simple answer is that what one presupposes here is precisely the normative validity of positive law - the law that is practiced by a certain population. The validity of the basic norm, as noted briefly earlier, is conditional on its 'efficacy'. The content of the basic norm of any given legal system is determined by the actual practices that prevail in the relevant community". 
społeczny, polegający na przestrzeganiu przez daną społeczność pewnego systemu prawnego. To dzięki efektywności dany system obowiązuje. Reasumując, Marmor uważa, że Kelsen zredukował treść normy podstawowej do obowiązywania systemu, które jest faktem socjologicznym, a więc zredukował prawo do faktów. Równocześnie Marmor stwierdza, że obowiązywanie danego systemu a kwestia jego normatywności to dwa odrębne zagadnienia. Należy się z tym drugim stwierdzeniem zgodzić. Problem jednak polega na tym, że to właśnie istota normy podstawowej ma być podstawą normatywności. Określając więc sedno normy podstawowej jako obowiązywanie systemu, Marmor stawia znak równości pomiędzy obowiązywaniem a normatywnością (definiowaną przezeń jako dostarczanie racji do działania zgodnie $\mathrm{z}$ danym systemem prawnym). Jest to już w świetle teorii Kelsena nie do przyjęcia. Kelsen rygorystycznie oddzielał obie kwestie i nawet jeżeli uzasadniał obowiązywanie socjologicznie, to na pewno nie redukował normy podstawowej do faktów socjologicznych. Odrzucając systemy statyczne (a zatem takie, które pozwalają na bezpośrednie wydedukowanie treści norm prawnych z normy podstawowej) i uznając systemy prawne za systemy dynamiczne (bazujące na delegacji kompetencji do ustanawiania norm prawnych), Hans Kelsen wyraźnie wskazał, że postrzegał sens normy podstawowej w stwarzaniu kompetencji ${ }^{4}$. Co więcej, był on relatywistą normatywnym. Uważał, że norma podstawowa może wskazywać różne i dowolne autorytety jako wyposażone w kompetencję. Jedynym wspólnym elementem różnych systemów prawnych jest samo istnienie normy podstawowej, która jest źródłem normatywności. Kelsen nie redukował nauki prawa do żadnej z nauk deskryptywnych, ale wyjaśniał obowiązywanie prawa poprzez założenie normy podstawowej.

Redukcja może służyć wyjaśnieniu zjawiska normatywności. Normatywność dla Marmora to zdolność do dostarczania racji postępowania zgodnego z prawem, a więc uzasadnienie powinności. Redukcja może uzasadniać powinność - uzasadniać, dlaczego przestrzegamy norm należących do danego systemu prawnego. Kelsen jest relatywistą i stwierdza, że dla społeczeństw autorytety wskazane w normie podstawowej różnych systemów prawnych mogą być rozmaite, ale łączy je jedno: istnienie normy podstawowej, które jest źródłem normatywności. Założenie normy podstawowej jest źródłem normatywności.

To nie samo istnienie normy podstawowej, lecz jej treść (polegająca na wskazaniu autorytetu) dostarcza nam racji działania. Kelsen wskazuje tylko źródło normatywności (kompetencję), a nie samą normatywność. Nie dokonuje zatem żadnej redukcji, czy to konstytutywnej, czy semantycznej.

Teoria Kelsena ma być uniwersalna i stosować się do każdego pozytywnego systemu prawnego, stąd relatywizm normatywny (norma podstawowa może wskazywać różne autorytety, co więcej, wskazuje ona autorytety, które mogą ustanawiać prawo o różnej treści).

${ }^{4}$ H. Kelsen, General Theory of Law and State, Harvard 1949, s. 155. 
Kelsen zakłada więc tylko istnienie normy podstawowej. Natomiast norma podstawowa może wskazywać różne autorytety, a przez to różne racje do działania ${ }^{5}$. Normatywność rozumiana jako dostarczenie obiektywnych racji do działania jest pojęciem chronologicznie późniejszym wobec czystej teorii prawa, dlatego sam Kelsen nie posługuje się taką definicją.

\section{Obowiązywanie systemu prawnego a przestrzeganie norm prawnych}

Marmor podkreśla, że dla Kelsena efektywność (efficacy) jest warunkiem obowiązywania danego systemu. Natomiast każda pojedyncza norma prawna, będąca częścią danego systemu, nie musi być efektywna, wystarczy, że efektywny (przestrzegany) jest system prawny jako całość. Tak więc nawet nieefektywna norma (nikt jej nie przestrzega) dalej pozostaje częścią danego systemu, który nadal obowiązuje. To system musi być przestrzegany jako całość, a nie każda pojedyncza norma ${ }^{6}$.

Natychmiast jednak nasuwa się pytanie o granice efektywności i obowiązywania, a więc pytanie o to, ile norm może być w danym systemie nieprzestrzeganych, aby system ten nadal obowiązywał. Czy wystarczy, aby była przestrzegana tylko jedna, dwie bądź trzy normy? A co w sytuacji, gdy żadna z norm nie jest przestrzegana - czy system nadal obowiązuje, ponieważ nie został derogowany?

Należy podkreślić, że kwestia obowiązywania danej normy prawnej nie ma charakteru czysto kauzalnej konieczności. Kauzalność opisują prawa nauki, np. prawa fizyki; jest to modalna konieczność, np. metal w wysokiej temperaturze zawsze zwiększa swoją objętość (taka konieczność może zawsze zostać podważona poprzez doświadczenie przeciwne).

5 J. Raz, Kelsen's theory of the basic norm, „The American Journal of Jurisprudence” 1974, s. 1: „According to Kelsen's theory it is logically necessary that in every legal system there exist one basic norm. The basic norm can be said to exist for Kelsen says that it is valid, and validity is the mode of existence of norms. This does not mean that all basic norms are identical in content. Indeed, no two basic norms can have the same content. They are all called basic norms not because of their content but because they all share the same structure, the same unique position each in its own system, and because they all perform the same functions".

6 A. Marmor, op. cit., s. 19: „A norm is efficacious if it is actually (generally) followed by the relevant population. Thus, 'a norm is considered to be legally valid', Kelsen wrote, 'on the condition that it belongs to a system of norms, to an order which, on the whole, is efficacious'. So the relationship is this: Efficacy is not a condition of legal validity of individual norms. Any given norm can be legally valid even if nobody follows it. (For example, think about a new law, just enacted; it is legally valid even if nobody has yet had an opportunity to comply with it.) However, a norm can only be legally valid if it belongs to a system, a legal order that is by and large actually practiced by a certain population. And thus the idea of legal validity, as Kelsen admits, is closely tied to this reality of a social practice; a legal system exists, as it were, only as a social reality - a reality that consists in the fact that people actually follow certain norms". 
Jeśli ktoś jest do czegoś obowiązany, to jeżeli tego nie uczyni, nie oznacza to, że norma nakładająca obowiązek musi zostać zmieniona. Gdyby jednak metal w wysokiej temperaturze nie zwiększył kiedyś objętości, oznaczałoby to, że prawo fizyczne o treści: „każdy metal zwiększa objętość w wysokiej temperaturze” należy sfalsyfikować?.

Zatem nawet jeżeli dana norma prawna nie jest przestrzegana, to nadal obowiązuje. Dużo bardziej problematyczna jest kwestia obowiązywania całego sytemu prawnego, bowiem co zrobić w sytuacji, gdy żadna z norm danego systemu prawnego nie jest przestrzegana? Czy system przestaje wtedy obowiązywać? Przecież można sobie wyobrazić sytuację, w której społeczeństwo nie przestrzega danego systemu prawnego, a mimo to on nadal obowiązuje. Czy zatem obowiązywanie systemu ma charakter zbliżony do kwestii obowiązywania pojedynczej normy prawnej? Jeżeliby przyjąć takie rozwiązanie, to uzasadnienie obowiązywania jako faktu społecznego stałoby się bezużyteczne - system obowiązywałby pomimo tego, iż nikt go nie przestrzega. To oznaczałoby, że obowiązywanie nie jest tożsame $\mathrm{z}$ efektywnością. Kelsen wydaje się jednak utożsamiać obowiązywanie (validity) z efektywnością. Jeżeli system prawny nie jest przestrzegany, to przestaje obowiązywać (potwierdza to przykład rewolucji: zmiana reżimu powoduje nieprzestrzeganie przez społeczeństwo poprzedniego systemu prawnego i przestaje on obowiązywać) ${ }^{8}$, natomiast może on dalej być systemem legitymowanym (follow the principle of legitimacy), dopóki nie zostanie derogowany w sposób, jaki sam przewiduje. Obowiązywanie systemu prawnego jest zatem bardzo swoistą kategorią: nie jest to zjawisko kauzalne, ponieważ nie wystarczy jedna nieprzestrzegana norma, aby dany system przestał obowiązywać (tak jest w przypadku prawa fizyki - wystarczy jeden wyjątek, aby obalić całe prawo). Zastanówmy się jednak, czy obowiązywanie

7 H. Kelsen, The Pure Theory of Law, Berkeley-Los Angeles 1970, s. 88: „If a fact is found that is in conflict with the law of nature, then science must abandon that law as inaccurate and replace it by another that conforms with the fact. But if some behavior is not in conformity with the legal norm-provided such behavior is relatively infrequent - the science of law has no reason to regard as invalid the violated legal norm, no reason to replace the legal norm-proposition describing the law by another legal norm-proposition. The laws of nature formulated by natural science must conform to the facts, but the facts of human action and refrainment ought to conform to the legal norms described by the science of law".

8 H. Kelsen, General Theory..., s. 118: „This shows that all norms of the old order have been deprived of their validity by revolution and not according to the principle of legitimacy. And they have been so deprived not only de facto but also de jure. No jurist would maintain that even after a successful revolution the old constitution and the laws based thereupon remain in force, on the ground that they have not been nullified in a manner anticipated by the old order itself. Every jurist will presume that the old order - to which no political reality any longer corresponds - has ceased to be valid, and that all norms, which are valid within the new order, receive their validity exclusively from the new constitution. It follows that, from this juristic point of view, the norms of the old order can no longer be recognized as valid norms". 
systemu może stanowić kategorię analogiczną do przestrzegania pojedynczej normy prawnej. Pełnej analogii w kwestii obowiązywania systemu nie ma, ponieważ istnieje taka sytuacja, w której żadna z norm nie jest przestrzegana i wtedy cały system nie.

Marmor jednoznacznie stwierdza, że Kelsen uznaje obowiązywanie systemu za treść normy podstawowej i tym samym redukuje prawo do faktów socjologicznych (przestrzegania przez społeczeństwo systemu prawnego). Przede wszystkim takie twierdzenie jest niezgodne $\mathrm{z}$ Kelsenowskim relatywizmem normatywnym. Kelsen nie zgadza się na jedną, obiektywną treść normy podstawowej; uważa, że jest ona zmienna (ponieważ może wskazywać różne autorytety, tworzące różne prawo). Po drugie, Kelsen podkreśla, że zawartość normy podstawowej jest normatywna. Obowiązywanie systemu prawnego jest skutkiem, konsekwencją przyjęcia założenia istnienia normy podstawowej. Jeżeli sednem normy podstawowej będzie obowiązywanie systemu, albo ściślej - posługując się terminologią Marmora - racją przestrzegania danego systemu będzie fakt, że jest on przestrzegany, popadniemy w błędne koło. Marmor stwierdza, iż system obowiązuje, ponieważ społeczeństwo go przestrzega, a przestrzega go dlatego, że system ten obowiązuje (idem per idem).

Jeżeli ktoś twierdzi, iż przestrzega danego systemu dlatego, że inni go przestrzegają, to według Josepha Raza odwołuje się do innego pojęcia socjologicznej normatywności. Kelsen nie uznaje takiej normatywności, ponieważ nie pozwala ona odróżnić prawa od rozkazów np. gangu przestępczego ${ }^{9}$. Zatem ktoś, kto twierdzi, że przestrzega danego systemu prawnego, ponieważ inni go przestrzegają, jedynie naśladuje zachowania obserwowane dookoła siebie, natomiast nie przyjmuje założenia istnienia normy podstawowej.

Obowiązywanie systemu utożsamiane $\mathrm{z}$ efektywnością pozostaje $\mathrm{w}$ sferze faktów (socjologicznych), a nie powinności. Tak pojęte obowiązywanie jest jedynie pewnym warunkiem praktycznym istnienia systemu prawnego. Jest to kategoria pozwalająca nam zawęzić nasze pole zainteresowania naukowego do tego zjawiska, które jest istotne, a więc tego „właściwego” systemu prawnego, a nie jakiegoś sztucznego tworu społecznie irrelewantnego.

Ciekawe jest spostrzeżenie Marmora, iż Kelsen, używając przykładu rewolucji, stwierdził, że zmiany w rzeczywistości (np. obalenie monarchii) powodują zmiany treści normy podstawowej, a więc dedukował z faktów powinność, co podpada pod gilotynę Hume'a. Nasuwa się jednak pytanie: czy w przypadku rewolucji zmiany w rzeczywistości nie są poprzedzone zmianą racji przestrzegania

9 J. Raz, op. cit., s. 7: „Kelsen claims in effect that the concept of social normativity is not a concept of normativity at all. It does not allow the interpretation of law as imposing obligations, granting powers, rights, etc. It makes the law indistinguishable from the commands of a group of gangsters terrorizing the population of a certain area. Only by using the concept of justified normativity can one understand the true character of legal systems as normative systems". 
danego systemu, a więc zmianą w sferze normatywnej (np. racją przestrzegania danego systemu przestaje być fakt, że dany system ustanowił monarcha)? Gdy system prawny przestaje być efektywny, to przestaje obowiązywać, a przyczyną tego są zmiany w sferze normatywnej, w treści normy podstawowej.

\section{Zarzut Marmora}

Marmor zarzuca Kelsenowi, że nie próbuje wskazać racji działania, które są według niego sednem normy podstawowej, a tym samym pomija pytanie o normatywność. Przyjrzyjmy się bliżej tej kwestii:

I have also tried to show that there is something misguided about Kelsen's explanation of the normativity of law. Kelsen was right to assume that normativity can only be understood in terms of reasons for action; but when the question arises as to what kind of reasons these are, and what makes them reasons, Kelsen just invites us to stop asking ${ }^{10}$.

Istota normy podstawowej zawiera przyczyny, dla których warto dokonać założenia jej istnienia. Ponieważ sama treść normy podstawowej może być różna, to - posługując się terminologią Marmora - również racje, dla których przyjmujemy założenie jej istnienia, mogą być bardzo różne. Dlatego dla Kelsena normatywność tkwi w istocie normy podstawowej, a jej źródłem jest fakt przyjęcia założenia jej istnienia. Nie można wskazać jednego konkretnego autorytetu, dla którego warto przestrzegać danego systemu prawnego. Jest to Kelsenowski relatywizm. Nie jest więc tak, że Kelsen zakazuje nam zadawać pytania o racje przestrzegania danego systemu. Odpowiedź na to pytanie po prostu nie jest konieczna w świetle czystej teorii prawa.

Od powyższego należy odróżnić problem obowiązywania systemu prawnego, który Kelsen łączy z efektywnością (efficacy), czyli powtarzalnością zachowań ludzkich (fakt socjologiczny). Efektywność ta nie musi odnosić się do każdej normy prawnej z osobna, lecz do systemu jako całości. Ponadto obowiązywanie wydaje się pojęciem nieostrym, gdyż trudno określić granicę (czyli liczbę nieprzestrzeganych norm), powyżej której system prawny przestaje obowiązywać.

\section{Pojęcie redukcji}

Kelsen sprowadza prawo do samego założenia istnienia normy podstawowej, która jest źródłem normatywności. Mamy zatem do czynienia ze ścisłym rozróżnieniem sfery bytu (sein) i powinności (sollen). Brak jest w czystej teorii prawa redukcji konstytutywnej, czyli redukcji prawa do faktów społecznych, ponieważ doprowadziłoby to do przełamania rygorystycznego dualizmu ontologicznego

\footnotetext{
${ }^{10}$ A. Marmor, op. cit., s. 28.
} 
Kelsena. Ponadto autor ten z całą pewnością nie redukuje nauki prawa do żadnych nauk deskryptywnych, takich jak np. socjologia, lecz sprowadza ją do treści normatywnych, a więc niereduktywnych.

Zawartość normy podstawowej, dostarczająca np. racji działania (zgodnie z terminologią, którą posługuje się Marmor), a więc normatywna, może być w tym zakresie (tj. twierdzeń normatywnych) dowolna. Mogą to być np. autorytety moralne, religijne, sprawiedliwościowe, ideologiczne itd.

\section{Relacja normy podstawowej i obowiązy wania systemu w teorii Kelsena}

Dla Kelsena norma podstawowa jest podstawą obowiązywania danego systemu norm prawnych. System prawny obowiązuje, ponieważ jest efektywny, czyli przestrzegany przez społeczeństwo. A jest on przestrzegany przez społeczeństwo ze względu na założone istnienie normy podstawowej, której zawartość jest normatywna.

W świetle powyższego tym bardziej nietrafne wydaje się spostrzeżenie Marmora, że sednem normy podstawowej w teorii Kelsena jest obowiązywanie systemu czy też jego efektywność. Przyjmując jego rozumowanie, wpadamy bowiem w błędne koło: stwierdzamy, że system obowiązuje, ponieważ społeczeństwo go przestrzega, a przestrzega go dlatego, że system ten obowiązuje - idem per idem.

Przestrzeganie danego systemu prawnego przez społeczeństwo, a więc obowiązywanie go jest konsekwencją przyjęcia założenia istnienia normy podstawowej.

Marmor niesłusznie stwierdził, że Kelsen nie dostarczył racjonalnych argumentów skłaniających nas do przyjęcia założenia istnienia normy podstawowej. Przede wszystkim należy ponownie podkreślić, iż pojęcie normatywności jako obiektywnych racji działania jest pojęciem chronologicznie późniejszym wobec czystej teorii prawa, zatem sam Kelsen nie mógł się do niej odnieść. Ponadto wskazanie konkretnych, obiektywnych racji nie jest niezbędne w świetle założeń czystej teorii. Samo założenie Grundnorm jest konieczne, jeżeli chcemy, aby system istniał (brak założenia oznacza brak systemu i anarchię - Kelsen dopuszcza i taką możliwość). Natomiast treść normy podstawowej, ze względu na normatywny relatywizm Kelsena, może być rozmaita (może ona wskazywać różne autorytety). Dlatego nie jest konieczne wskazanie konkretnych, obiektywnych racji przestrzegania systemu prawnego.

\section{Podsumowanie}

Czysta teoria prawa Hansa Kelsena już w założeniu, jak zauważa Stanley L. Paulson, miała być swoistą trzecią drogą, alternatywą dla dychotomicznego podziału teorii prawa na teorie prawnonaturalne i pozytywistyczne. Miała ona 
dostarczyć nowej, odpolitycznionej wizji i definicji prawa. Co więcej, Kelsen nie tylko podkreślał tezę o rozdziale prawa i moralności, lecz także rozdział prawa i faktów, a zatem stawiał silną tezę o normatywności ${ }^{11}$. Takie założenia powodują, że przyjęcie wizji Marmorowskiej redukcji (w szczególności konstytutywnej) jest niemożliwe, bowiem godziłoby w same założenia czystej teorii prawa.

${ }^{11}$ H. Kelsen, Introduction to the problems of Legal Theory, Oxford 1934, s. 27. 